\title{
Equity Crowdfunding, Shareholder Structures, and Firm Performance
}

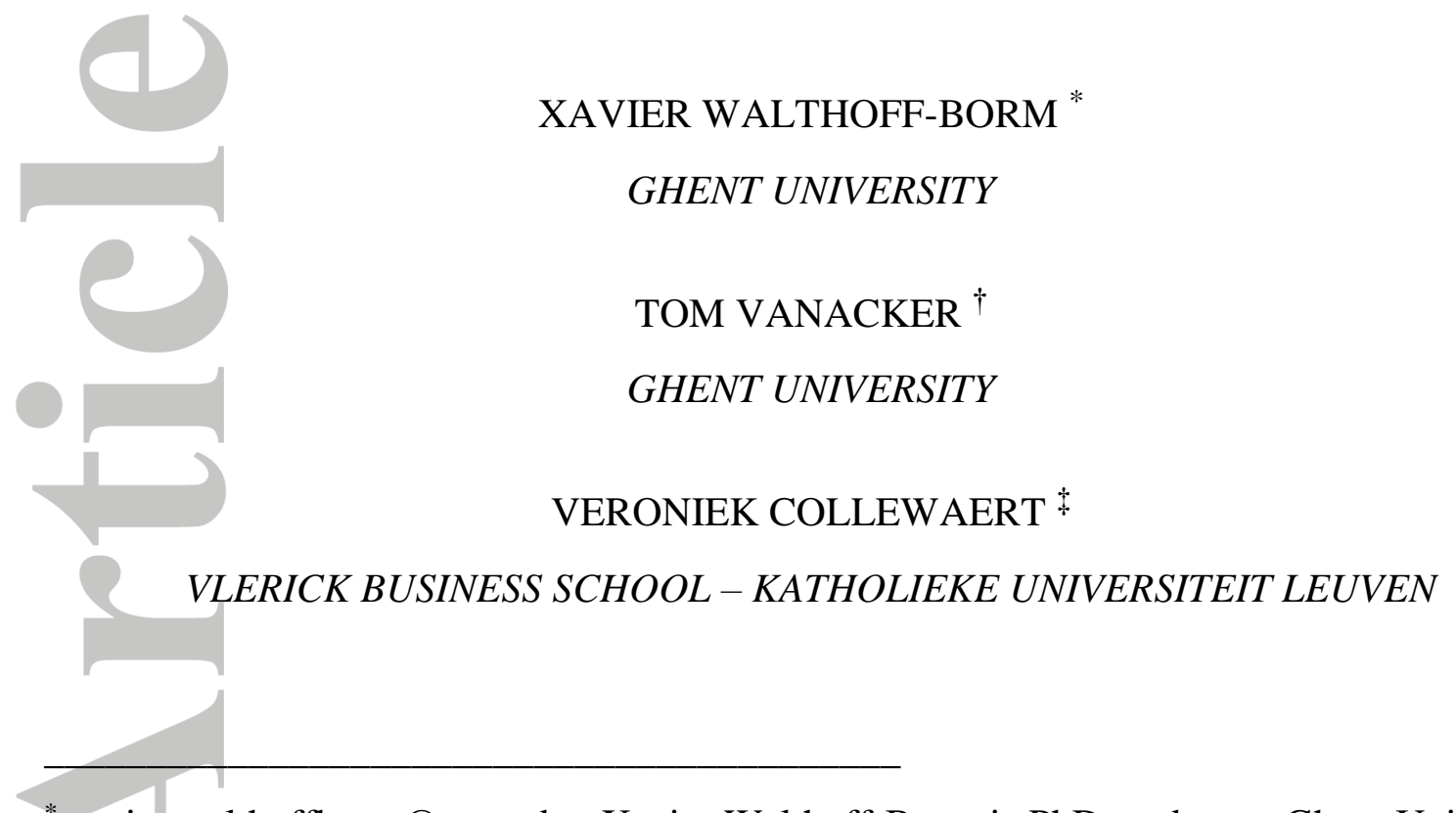

*xavier.walthoffborm@ugent.be. Xavier Walthoff-Borm is PhD student at Ghent University. He received funding from the Research Foundation - Flanders to investigate the equity crowdfunding phenomenon. He has been visiting scholar at Politecnico di Milano (2018). His research has been presented at various conferences in management and entrepreneurship including the Babson College Entrepreneurship Research Conference and the Academy of Management Annual Meeting. His research has been published in Journal of Business Venturing.

$\dagger$ tomr.vanacker@ugent.be. Tom Vanacker is Associate Professor at Ghent University. His research is focused on entrepreneurial finance. In particular, he explores new venture financial resource acquisition and its implications for firm performance. His research has been published in Entrepreneurship Theory and Practice, Journal of Banking \& Finance, Journal of Business Venturing, Journal of Management Studies, Organization Science, and Strategic Management Journal, among others.

¥ veroniek.collewaert@kuleuven.be. Veroniek Collewaert is Associate Professor at Vlerick Business School. Her research is focused on relational dynamics between investors and entrepreneurs, and strategic considerations in the investor-entrepreneur relationship. She has published in Entrepreneurship Theory and Practice, Journal of Management, Journal of Management Studies, and Strategic Management Journal, among others.

ACKNOWLEDGEMENTS. We are grateful to the Editors, anonymous CGIR reviewers and Giancarlo Giudici for constructive feedback. A prior version of this paper also benefited from feedback at the 2017 CGIR Workshop "Corporate governance implications of new methods of entrepreneurial firm formation" (University of Bergamo). We acknowledge financial support from the Research Foundation-Flanders [Grant \# G012716N].

This article has been accepted for publication and undergone full peer review but has not been through the copyediting, typesetting, pagination and proofreading process which may lead to differences between this version and the Version of Record. Please cite this article as doi: $10.1111 /$ corg. 12259 


\section{Equity Crowdfunding, Shareholder Structures, and Firm Performance}

\section{ABSTRACT}

Manuscript Type: Empirical

Research Question/Issue: This paper provides a first-time glimpse into the post-campaign financial and innovative performance of equity-crowdfunded (ECF) and matched non-equitycrowdfunded (NECF) firms. We further investigate how direct and nominee shareholder structures in ECF firms are associated with firm performance.

Research Findings/Insights: We find that ECF firms have 8.5 times higher failure rates than matched NECF firms. However, 3.4 times more ECF firms have patent applications than matched NECF firms. Within the group of ECF firms, we find that ECF firms financed through a nominee structure make smaller losses, while ECF firms financed through a direct shareholder structure have more new patent applications, including foreign patent applications.

Theoretical/Academic Implications: Our findings suggest that there are important adverse selection issues on equity crowdfunding platforms, although these platforms also serve as a catalyst for innovative activities. Moreover, our findings suggest that there is a more complex relationship between dispersed versus concentrated crowd shareholders and firm performance than currently assumed in the literature.

Practitioner/Policy Implications: For policymakers and crowdfunding platforms, investor protection against adverse selection will be important to ensure the sustainability of equity crowdfunding markets. For entrepreneurs and crowd investors, our study highlights how equity crowdfunding and the adopted shareholder structure relate to short-term firm performance.

Keywords: Equity Crowdfunding, Corporate Governance, Direct Shareholder Structure, Nominee Structure, Firm Performance. 


\section{INTRODUCTION}

Entrepreneurs require financial resources to form and grow their firms, yet internal funds are rarely sufficient to fuel entrepreneurs' aspired growth (e.g., Cassar, 2004; Cosh et al., 2009; Vanacker \& Manigart, 2010). Moreover, young and small firms often experience significant problems in acquiring external funds (Berger \& Udell, 1998; Carpenter \& Petersen, 2002)— problems that have worsened after the global financial crisis (Block \& Sandner, 2009; Cowling et al., 2012). More recently, crowdfunding represents a 'new' source of financing that plays a progressively more important role in the financing of entrepreneurial firms (Bellavitis et al., 2017; Block et al., 2018a; Bruton et al., 2015; Cumming \& Vismara, 2017; Fleming \& Sorenson, 2016; Short et al., 2017).

In line with the increasing popularity of crowdfunding, scholarly research has followed suit with early research mainly focusing on (a) identifying success factors in raising different types of crowdfunding and (b) funding dynamics on crowdfunding platforms (e.g., Ahlers et al., 2015; Allison et al., 2015, 2017; Block et al., 2018b; Butticè et al., 2017; Chan \& Parhankangas, 2017; Colombo et al., 2015; Courtney et al., 2017; Davis et al., 2017; Giudici et al., 2018; Mollick, 2014; Vismara, 2016, 2018; Vulkan et al., 2016). Scholars have also started exploring post-campaign outcomes, with a primary focus on the follow-on funding and survival of projects funded through reward-based crowdfunding platforms (e.g., Butticè et al., 2017; Colombo \& Shafi, 2016; Mollick, 2014; Mollick \& Kuppuswamy, 2014). Few studies, however, have focused on the outcomes of firms funded through equity crowdfunding ${ }^{1}$, which is fundamentally different from reward-based crowdfunding (Vismara, 2018). Notable exceptions include Drover et al. (2017), Hornuf and Schmitt (2017), and Signori and Vismara (2018). In particular, these studies have examined follow-on fundraising, failures, and exits. ${ }^{2}$ We build on and extend this stream of research by providing a dynamic picture of firm financial and innovative performance and by comparing the 
performance of equity-crowdfunded firms to similar firms that have raised other sources of capital. Finally, equity crowdfunding platforms adopt different shareholder structures (Hornuf \& Schwienbacher, 2018), but we lack an insight on how this heterogeneity relates to firm performance (Cumming \& Wright, 2017).

We address these gaps and ask the following related research questions: How do equity crowdfunded (ECF) firms perform relative to matched non-equity crowdfunded (NECF) firms that raised other forms of capital? And, how do ECF firms financed through a direct shareholder structure perform relative to ECF firms financed through a nominee structure? How ECF firms perform is a critical question because corporate governance issues may be particularly important in this setting. Indeed, equity crowdfunding is the only form of crowdfunding where a potentially large number of new shareholders enter the firm (Bruton et al., 2015). Moreover, contrary to reward-based campaigns that are launched mostly by individuals and often represent artistic projects that generally do not relate to a firm, in equity crowdfunding the proponent is always a firm (Vismara, 2018). Finally, the equity crowdfunding context is characterized by significant information asymmetries, where small crowd investors may have limited resources and incentives to perform detailed due diligence and monitoring activities (Ahlers et al., 2015).

Our research also connects and contributes to a broader literature. First, a large literature has shown that ownership type and structure may substantially affect firm performance (e.g., Dalton et al., 2003; Kumar \& Zattoni, 2017). Within the domain of equity financing, for instance, studies have shown that there are significant differences in the postinvestment growth and failure rates of venture capital-backed versus non-venture-capitalbacked firms (Manigart et al., 2002; Puri \& Zarutskie, 2012). Similarly, others have shown differences in the post-investment evolution of angel-backed versus non-angel-backed firms (Collewaert et al., 2010). However, findings from these studies are not necessarily 
generalizable to ECF firms because various differences exist between traditional outside equity financing, and equity crowdfunding. For example, while traditional outside equity investors often rely on detailed due diligence to reduce adverse selection issues, equity crowdfunding relies on the wisdom of the crowd (Schwienbacher \& Larralde, 2012). Moreover, while outside equity investors are often actively involved in their portfolio firms to reduce potential moral hazard issues and to add value, equity crowd investors are more passive within the firms they finance (Block et al., 2018a). Still, equity crowd investors may provide valuable feedback and become brand ambassadors for the firm and its products (Schwienbacher \& Larralde, 2012). In this paper, we will thus provide a first-time glimpse into how ECF firms perform relative to NECF firms that raised other forms of capital. ${ }^{3}$

Second, not all equity crowdfunding is the same and the equity crowdfunding context provides a unique context for examining different shareholder structures in young entrepreneurial firms (e.g., Cumming \& Wright, 2017). As Filatotchev and Wright (2017: 11) observe "in studies on entrepreneurial firms there is oftentimes a lack of recognition of the different ownership structures and goals which may affect the structure and processes of governance". In this paper, we compare the performance of firms that received equity crowdfunding through a direct shareholder structure, wherein crowd investors become legal shareholders of the business they support, to the performance of firms that received equity crowdfunding through a nominee structure, wherein equity crowdfunding platforms hold and manage the shares of the supported firms on behalf of the crowd investors. This comparison will further allow us to provide new insights into the benefits of concentrated versus dispersed crowd shareholders (e.g., Kumar \& Zattoni, 2017).

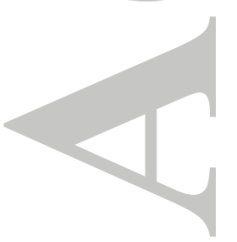




\section{HYPOTHESES}

\section{Equity Crowdfunding and Firm Performance}

There are several reasons to expect that ECF firms might outperform NECF firms that raised other sources of capital. These reasons include equity crowdfunding's unique selection mechanism - "the wisdom of crowds" — and extra-financial benefits.

First, firms that successfully raise equity crowdfunding survived "the wisdom of the crowd"; this principle entails that the crowd displays more wisdom than an individual (even an expert) when solving problems or making decisions (Schwienbacher \& Larralde, 2012; Surowiecki, 2005). The wisdom of the crowd effect relies on filtering out noise in individual problem solving, by averaging over large numbers and thereby canceling out the effect of individual noise (Surowiecki, 2005). While wisdom of the crowd effects have been primarily examined for relatively simple problems that require single estimates, there is evidence that this effect is also valid for problems or decision making that require the coordination of multiple pieces of information (Yi et al., 2012), such as investment decision making.

Moreover, recently, there is also evidence of wisdom of crowd effects in rewardbased crowdfunding (Mollick \& Nanda, 2016) and lending-based crowdfunding (Iyer et al., 2015) contexts. Mollick and Nanda (2016), for instance, find large agreement between the funding decisions of crowds and experts related to theatre projects. In addition, they fail to find quantitative or qualitative differences between projects selected by the crowd alone and those selected by both the crowd and experts. Thus, while each individual crowd investor may have relatively limited resources (such as industry knowledge) and economic incentives to perform due diligence, combined, the crowd could succeed in selecting firms with greater financial and innovative potential. After all, multiple perspectives and backgrounds should foster smarter decision making in ways that simple experience or knowledge does not (Mollick \& Nanda, 2016; Mollick \& Robb, 2016). ${ }^{4}$ Generally speaking, the benefits of speed, 
scale, and diversity in experience and background of crowd investors ensure a unique selection mechanism that may be superior to that of any individual even when that individual is an expert. These wisdom of the crowd effects thus entail that crowds can select firms with greater financial and innovative potential, which in turn could result in better post-investment performance for ECF firms compared to NECF firms that did not undergo such crowd scrutiny.

Second, next to its unique selection mechanism, equity crowdfunding may have nonfinancial benefits that contribute to firm performance. For example, the equity crowdfunding campaign provides a forum from which ECF firms may obtain valuable feedback (Belleflamme et al., 2014). In general, the value of customer feedback and the importance of leveraging the crowd for the development of products and services has long been recognized in the marketing and innovation management literature (e.g., Lovelock \& Young, 1979; Gruner \& Gomburg, 2000; Prahalad \& Ramaswamy, 2004, Mahr et al., 2013). By incorporating (prospective) customer preferences into new products or services ECF firms might foster new product success and spur firm innovation (e.g., Joshi \& Sharma, 2004). Especially, firms that suffer from liabilities of newness and smallness would benefit from customer participation (Chang \& Taylor, 2016).

Even though crowd investors are investors, and thus sensu stricto not customers, there is evidence that their behavior conforms to customer participation as they invest to become part of the entrepreneurial firm. Indeed, recent studies highlight that crowdfunding participants are intrinsically motivated to take an active role in the innovation conversation (e.g., Stanko \& Henard, 2017). Supporting their knowledge contribution, some crowdfunding participants have been granted advisory board positions because of their exceptional knowledge and experience. Also, various entrepreneur testimonials echo that engaged crowd investors offer more than just money; entrepreneurs acknowledge that they solicited the 
crowd for feedback and responded to this feedback with adjustments to product design, marketing and pricing strategies to ensure a timely and successful commercialization (Grell et al., 2015). Moreover, Schwienbacher and Larralde (2012) argue that investors can become ambassadors and may "crowd-brand" the company to others, thereby spurring commercialization. Finally, successful equity crowdfunding campaigns can create market awareness and visibility (Schwienbacher \& Larralde, 2012), which is often essential for young and small firms that need to attract additional resources to support their development (Vanacker \& Forbes, 2016).

NECF firms that raise other sources of capital may also benefit from extra-financial resources. For instance, venture capital and angel investors provide value-adding services (e.g., Sapienza et al., 1996). However, it is important to acknowledge two points. First, research findings on the performance effects of receiving venture capital are mixed. In their meta-analysis, Rosenbusch et al. (2013) synthesize 76 empirical samples on 36,567 firms and find only a negligible effect of venture capital on firm financial performance. Second, and more importantly, the majority of firms do not raise venture capital or angel investments (Cosh et al., 2009); they are unable or unwilling to do so. ${ }^{5}$ Thus, new capital generally comes from additional investments made by the entrepreneurs themselves, family members or friends. These (internal) sources of capital generally do not provide extra-financial benefits. Combined, the extra-financial benefits in NECF firms that raise other sources of capital are generally very limited.

Taken together, equity crowdfunding's unique selection mechanisms and/or extrafinancial benefits should enhance an ECF firm's financial and innovative performance relative to NECF firms that raise capital from other sources. Thus,

Hypothesis 1. ECF firms will exhibit higher (a) financial and (b) innovative performance, relative to matched NECF firms that raised other sources of capital. 


\section{Shareholder Structures and Firm Performance in Equity Crowdfunding}

Not all equity crowdfunding platforms work in the same way, however (Cumming \& Wright, 2017; Hornuf \& Schwienbacher, 2018). Specifically, shareholder structures may vary across equity crowdfunding platforms. One possibility is a direct shareholder structure wherein each crowd investor becomes a direct shareholder of the firm he or she funds. Another possibility is the nominee structure wherein the crowd is represented by one legal shareholder (i.e. the nominee) who holds the shares on behalf of the crowd investors. While some equity crowdfunding platforms use a nominee structure, others use a direct shareholder structure.

It is widely accepted in the corporate governance literature that concentrated ownership — associated with a nominee structure — reduces agency costs and, as such, results in improved firm performance (e.g., Barry et al., 1990; Jensen \& Meckling, 1976; Shleifer \& Vishny, 1997). This positive effect is mainly due to more efficient monitoring: higher ownership concentration makes it easier to act collectively because one has more incentive and power to monitor management. Moreover, as there are simply fewer owners to coordinate with, high ownership concentration is associated with lower coordination costs (Dharwadkar et al., 2000). We argue that a similar argument holds in equity crowdfunding and hence that ECF firms financed through a nominee structure should outperform ECF firms financed through a direct shareholder structure.

One of the key mechanisms through which investors can mitigate agency conflicts is through monitoring. In a direct shareholder structure, however, many small crowd investors may not only lack the power, but also the economic incentives to monitor (Ahlers et al., 2015). For individual crowd investors, it simply does not make economic sense to bear significant monitoring costs (even if they would have the power to influence management) given their relatively small investments and the possibility that others free-ride on their 
monitoring activities (e.g., Hart, 1995). Thus, the monitoring of management in ECF firms financed through a direct shareholder structure might be less than optimal.

Moreover, in a direct shareholder structure, the firm is expected to be faced with more constraints and expenses. First, the process of shareholder approval will be more complex, formalistic, expensive and lengthier. Shareholder approval is required for events such as director elections, fundamental changes to the constituent instruments of the company, recapitalizations, sales of significant assets and mergers. Consider, for instance, a typical firm raising $£ 200,000$ via equity crowdfunding from 144 backers in a direct shareholder structure. The large majority (75\%) of crowd investors have voting rights (Signori \& Vismara, 2018). When the firm would need follow-on financing, depending on the articles of association, all 144 crowd investors might need to be consulted, and crowd investors who are entitled to vote (let's assume $75 \%$, i.e. 108 individual investors) would need to sign and return a document to the firm. Some shareholders may be quite passive investors and therefore may have to be contacted repeatedly to get their approval. Moreover, the more ownership becomes dispersed, the more challenging it will be to align the interests of all crowd investors (Wang et al. 2015); i.e. they may simply disagree on what they consider to be the best solution. All of this combined results in a more costly decision-making process compared to a situation where the firm would only need to deal with one shareholder, as would be the case in a nominee structure.

Second, to get shareholder approval firms need to maintain a proper and up-to-date shareholder list. Again, maintaining such a list will likely be more complex and will take a lot of the entrepreneur's time and effort in a direct shareholder structure. This is an important issue as failing to properly maintain such a shareholder register may result in more professional investors shying away from the firm for follow-on financing. Moreover, being aware of the agency conflicts in a direct ownership structure and the complexity of 
shareholder management as described above, professional investors may be reluctant to invest in such firms (e.g., Drover et al., 2017). Indeed, a direct shareholder structure that results in more complex capitalization tables makes the administration and negotiation in financing rounds and exits more difficult. Further, for professional investors it is imperative that their portfolio companies scale quickly (Puri \& Zarutskie, 2012). Interacting with and convincing many separate crowdinvestors (rather than one nominee) may thus decrease decision speed and the odds of scaling successfully. Overall, there are several reasons why professional investors may be reluctant to provide follow-on financing to firms with dispersed crowd shareholders. Still, such financing may be crucial for firms to foster their development and allow them to exploit innovations. ${ }^{6}$

In contrast, a nominee structure has clear advantages compared to the direct shareholder structure. All else equal, given that nominees manage all crowd shares, they have more power and incentives to monitor relative to individual crowd investors. The individuals or firms that serve as nominees generally share in the value that is created at exit explaining their increased monitoring incentive. The fact that a firm only has to deal with one shareholder (i.e. the nominee) may further result in distinct effectiveness to reach shareholder approval. Nominee structures can thus be a means to create incentive alignment between crowd investors. In a nominee structure, the nominee also takes the role of legal representative, who has the capacity to make decisions on behalf of crowd investors. For example, in most cases, nominees have special rights (such as drag along and tag along rights) that allow them to make decisions for crowd investors when follow-on financing or an exit has to be negotiated. A nominee structure may, therefore, be a particularly important governance structure that enhances firm performance by reducing the negative effects arising from the agency conflicts in a direct ownership structure. Moreover, a nominee structure may lower coordination costs related to a dispersed direct ownership structure. 
Of course, if a nominee structure would only have advantages relative to a direct ownership structure, all entrepreneurs would choose that structure and it would be the only one we would observe. An advantage of the direct shareholder structure, and a particularly potent reason why entrepreneurs may prefer it, is that it allows entrepreneurs to retain more control over their firms. Entrepreneurs generally value control (Sapienza et al., 2003), and when each crowd investor is a direct shareholder, all else equal, they will have less power to influence entrepreneurs relative to a block of crowd shareholders that are managed and coordinated by a nominee. While retaining more control is valuable from the perspective of the entrepreneur, it does not necessarily benefit firm performance due to agency issues described above. Direct shareholdership might also foster "a feeling of belonging" by being more directly involved in an entrepreneurial firm (Belleflamme et al., 2014: 589). Such more direct involvement could benefit the provision of extra-financial resources from a broader, more diverse set of people, which could be particularly influential to obtain new ideas or perspectives. Ultimately, the disadvantages of a direct shareholder structure (i.e., agency conflicts and coordination costs) relate to such central issues in entrepreneurial finance and corporate governance that they are likely to outweigh the advantages of such a structure for firm performance. Thus,

Hypothesis 2. Within the group of ECF firms, firms that are financed through a nominee structure will exhibit higher (a) financial and (b) innovative performance, relative to matched firms that are financed through a direct shareholder structure. 


\section{METHOD}

\section{Empirical Setting}

In this section, we provide details on our empirical setting. We start with discussing equity crowdfunding and shareholder rights in the UK. We then further discuss the two UK-based platforms that we use for the purpose of our study, namely Crowdcube and Seedrs.

Equity crowdfunding and shareholder rights in the UK. Our empirical setting is the equity crowdfunding market in the UK, the largest and most developed equity crowdfunding market in Europe. The UK accounted for nearly $40 \%$ of the global equity crowdfunding market in 2016. Hence, this setting provides us with sufficient firms that raised equity crowdfunding (e.g., Harrison, 2013; Ralcheva \& Roosenboom, 2016; Signori \& Vismara, 2018; Vismara, 2016, 2018; Vulkan et al., 2016; Walthoff-Borm et al., 2018). Moreover, the UK has established equity crowdfunding platforms that operate through a direct shareholder structure, a nominee structure, or a combination of both. Finally, the UK setting provides accounting data on small, privately held firms (Walthoff-Borm et al., 2018). This data is crucial for our research because it allows us to track the performance of ECF firms and matched NECF firms over time.

Previous research has provided an excellent description of equity crowdfunding regulations in different countries including the UK (Hornuf \& Schwienbacher, 2017; Vismara, 2016). The types of shares that firms issue through equity crowdfunding campaigns are generally ordinary shares. Share rights are set out in the firm's articles of association and can entitle shareholders to dividends, participation in meetings of the firm, and voting rights (Vismara, 2016). The 2006 UK's Companies Act gives shareholders particular rights. ${ }^{7}$ For example, private firms do not need to hold an annual general meeting, but minority shareholders with at least $5 \%$ of the total voting rights are able to require the firm to call a general meeting. ${ }^{8}$ If shareholders wish to have more information about the proposed content 
of the meeting, those representing at least $5 \%$ of the total voting rights may also require the firm to circulate a statement of up to 1,000 words providing detail on the matters to be considered. Minority shareholders holding more than $10 \%$ of the shares also have the right to prevent a meeting from being held on short notice. Besides, they have the right to have the firm's annual accounts audited, at the firm's expense, even when the firm is exempted from an audit. This request must be made in writing and arrive at least one month before the end of the financial year that the audit is being asked for. The bundle of rights as minority shareholders is thus dependent on the percentage of the total voting rights or total shares. Further, company directors must often pass a resolution granting authority to allot new shares. If a decision is thought to be unfairly prejudicial to minority shareholders (e.g., in case of severe down rounds without compelling disclosures), a shareholder may bring an "unfair prejudice" claim. There is no minimum shareholding level for bringing such an action. ${ }^{9}$

The shares crowd investors purchase are difficult to trade (Signori \& Vismara, 2018). Recently though, equity crowdfunding platforms have started to experiment to increase liquidity. Some crowdfunding platforms with nominee structures have launched secondary markets. For example, Seedrs enables investors to trade shares at "fair value" to current investors in a given firm and when the firm is not subject to a major corporate transaction. Other platforms, such as Crowdcube, have organized an on-platform secondary share trade. In theory, crowd investors can also try to find an interested buyer to sell their shares to, subject to the firm's articles of association, but finding interested buyers is a major challenge.

Crowdcube and Seedrs. We focus on Crowdcube and Seedrs, two mature generalist equity crowdfunding platforms (Vismara, 2016). Both are London-based and are typically viewed as the UK's most active equity crowdfunding platforms. Together, they accounted for over $85 \%$ of all equity crowdfunding activity in 2016, with 134 deals for Crowdcube and 124 
deals for Seedrs. Both platforms are hence roughly similar in terms of market dominance. Crowdcube and Seedrs are also comparable in terms of the number of unique website visitors, with 146,454 and 147,650 monthly visitors, respectively (data from similarweb.com). Both platforms also require a minimum investment of $£ 10$ and the investment terms are set by the entrepreneur. Crowdfunding platforms differ significantly in their due diligence activities (Cumming \& Zhang, 2018). However, both Crowdcube and Seedrs have active due diligence standards. In 2015, firms had similar success rates on both platforms with just under 55\% of campaigns meeting or exceeding their targets. This suggests that - on average - the crowd views firms on both platforms as roughly equally investment ready.

A crucial difference between Crowdcube and Seedrs is their deal structuring. While Crowdcube uses a direct ownership structure, Seedrs uses a nominee structure. During much of the timeframe of our study, entrepreneurs themselves could not choose for a different shareholder structure on a specific platform (i.e. both on Crowdcube and Seedrs there was no choice option). ${ }^{10}$ This differentiation in deal structuring has been emphasized in the media and business press and was highlighted as a key distinction between both platforms by their respective founders. ${ }^{11}$

Under the direct ownership model, used by Crowdcube, the investors simply hold a direct equity investment in the firm. Depending on the presence of a possible investment threshold, they may receive A-shares with voting and preemptive rights when they invest at or above the threshold or receive B-shares without voting and preemptive rights when they invest below the threshold (Cumming et al., 2017). Crowdcube does not recommend any shareholders' agreement for the crowd. Under the nominee structure, however, used by Seedrs, voting right and direction power over the crowds' shares are held by the nominee. 
In the case of Seedrs, Seedrs Limited acts as the nominee. This means that the management board of Seedrs Limited consents on behalf of all individual shareholders. Seedrs does not appoint external nominees. It is the entire board that reviews and agrees on the decisions that come to Seedrs, as nominee, in relation to the portfolio companies. These decisions result from the subscription agreement between Seedrs and their portfolio companies. Each subscription agreement can be slightly different, but it will generally include consent rights in order to protect the investors. These consent rights cover things like winding-up the company, issuing preference shares, transferring assets out of the company, making certain loans or increasing director salaries beyond an agreed level. This means that a firm that has raised investment through Seedrs does not have to manage several individual investors, as Seedrs Limited is authorized to take votes and issue consents on behalf of each Seedrs investor.

This difference in deal structure between both platforms further has implications for the fee structure they employ. Crowdcube and Seedrs do not charge a fee to entrepreneurs who want to list on their platforms. Crowdcube charges a success fee of $7 \%$ (excl. VAT) on the amount firms successfully raise. Seedrs uses a two-layered fee structure. First, they also charge a success fee, which equals $6 \%$ of the amounts firms successfully raise, and there is a $£ 2,000$ completion fee (excl. VAT). Second, on investments held by Seedrs as the nominee, Seedrs charges a fee of $7.5 \%$ on any value realized (at an exit) in excess of the capital invested. Seedrs does not charge any management fee for acting as nominee. This second component of Seedrs' two-layered fee structure-similar to the "carried interest" in the venture capital setting (Gompers et al., 2009)—ensures that the interests of Seedrs (as a nominee) are aligned with those of crowd investors. 


\section{Data Sources and Samples}

We combined multiple data sources. We started from the current websites of Crowdcube and Seedrs. Next to both platforms' current websites, we used multiple online resources, including the Wayback machine and TechCrunch, to reconstruct the population of ECF firms. ${ }^{12}$ Using additional data sources is important because not all previously funded equity crowdfunding campaigns are archived on both platforms' current websites. Once we collected the ECF firms and their identifiers, we collected accounting data on these firms up to 2017. Disclosure requirements in the UK require privately held firms to publish annual accounting data on Companies House. We use Companies House as our primary data source to collect longitudinal accounting data on all of our sample firms from the year before the equity crowdfunding campaign up to 2 years after the campaign. Patent data is collected from Orbis Europe (formerly: Amadeus)—a database that comprises data on more than 2 million

UK firms and a product of Bureau Van Dijk (BvD). BvD obtains the patent data from the PATSTAT database, a worldwide database that contains bibliographical and legal status patent data and is maintained by the European Patent Office.

We start with the population of 260 UK firms that received equity crowdfunding on Crowdcube and 225 UK firms that received equity crowdfunding on Seedrs during the period of 2012 to 2015 (inclusive). The sample selection process was based on several steps. First, consistent with our focus on equity crowdfunding in entrepreneurial firms, we excluded firms active in real estate. Second, we also excluded non-UK firms that applied for equity crowdfunding. This selection step helps us to further reduce the heterogeneity that may arise in reporting requirements and regulation across countries. Finally, we excluded firms that never filed financial statements. We retained 250 unique firms that raised equity crowdfunding. 
ECF-NECF matched sample. To construct the matched sample, we started from Orbis Europe. We first identified those firms that raised capital, but did not do so through equity crowdfunding (i.e. NECF firms). A capital increase is defined as a net change in capital from period $\mathrm{t}-1$ to $\mathrm{t}$, normalized by the capital in period $\mathrm{t}-1$, in excess of $5 \%$ (Brav, 2009). We used a minimum threshold for the absolute amount of capital raised that equals the minimum equity financing amount of the ECF sample. We excluded firms that raised equity crowdfunding from Crowdcube, Seedrs or any other platform. We then used the coarsened exact matching and nearest neighbor matching algorithm (e.g., Bertoni et al., 2015) to select NECF firms that are similar to our ECF firms and raised capital in the same year. We perform all matching with replacement since Abadie and Imbens (2012) argue that this reduces possible biases. Accordingly, we matched each ECF firm based on its industry classification (i.e. Fama \& French industry code), firm size (i.e. total assets), firm age (i.e. years since incorporation), firm performance (i.e. profit or loss scaled by total assets) and intangible assets ratio (i.e. intangible assets to total assets) in the year of the first equity crowdfunding campaign (e.g., Puri \& Zarutskie, 2012). We collected longitudinal data from Companies House and Orbis Europe on these matched NECF firms up to 2017 as well. Together, this yielded a sample of 205 ECF and 205 NECF firms because it was not possible to find a good match for all ECF firms.

One particular concern with comparing ECF and NECF firms is distinguishing selection from causation. As King and Nielsen (2016: 1) argue, the matching procedure that we use:

"is an increasingly popular method for preprocessing data to improve causal inferences in observational data ... The goal of matching is to reduce imbalance in the empirical distribution of the pre-treatment confounders between the treated and control groups ... The resulting process amounts to a search for a data set that might have resulted from a randomized experiment but is hidden in an observational data set. When matching can reveal this "hidden experiment," many of the problems of observational data analysis vanish." 
However, matching does not allow us to perfectly distinguish selection from causation (see also Puri \& Zarutskie [2012], who are confronted with similar issues when comparing venture capital-backed and non-venture-capital-backed firms). However, it does allow us to make claims about differences between ECF and NECF firms (and between ECF firms financed through a direct ownership structure and ECF firms financed through a nominee structure) that are similar on specific observable characteristics (e.g., industry, firm size, firm age, firm performance and intangible asset ratio) at the time (one of the) firms receives equity crowdfunding. Thus, "simple" selection on these observable variables is unlikely to explain our results, But more subtle selection on unobservable variables may still matter.

Another commonplace concern with longitudinal data, particularly on new firms, is survivorship bias and sample attrition. In our data collection approach, however, we used multiple data sources to ensure that we capture all ECF firms funded through Crowdcube and Seedrs, irrespective of their current survival status. Some firms could fail very quickly after raising funds and this would make it impossible for us to collect accounting data on these firms. However, quick failures — and fraud cases — after successful crowdfunding campaigns are rare (e.g., Cumming et al., 2016; Mollick, 2014; Mollick \& Robb, 2016). Moreover, we do not limit our analysis to firms that remain active during the entire time frame of our study. Rather, firms are included as long as their relevant data are available, thereby further limiting survivorship bias (e.g., Lasfer, 1997). Finally, we explicitly investigate the probability that ECF and NECF firms fail over time, thereby providing us additional insights into firm failure dynamics. It is important to note that much of our sample size decrease over time is simply a consequence of the very young nature of the equity crowdfunding market. Specifically, most firms in our sample raised equity financing in 2015. This implies that they might not have reported additional financial accounts for up to two years by the end of 2017 (given delays between the closing of financial accounts and their publishing online in Companies House). 
ECF Direct - ECF Nominee matched sample. We further constructed another matched sample of ECF firms with a direct shareholder structure (funded through Crowdcube) and those with a nominee structure (funded through Seedrs) following a similar matching procedure as described above. We matched each ECF firm with a direct shareholder structure to an ECF firm with a nominee structure based on its industry classification, firm size and firm age. ${ }^{13}$ This yielded a second sample of 125 ECF firms with a direct shareholder structure and 125 ECF firms with a nominee structure. ${ }^{14}$ Given the limited number of ECF firms with a direct (nominee) shareholder structure, we did not add profitability and intangible assets ratios as additional matching variables because this would have reduced our sample. However, as we will detail below, both ECF firms with a direct shareholder structure and matched ECF firms with a nominee structure are already fairly similar in terms of profitability and intangible assets, even when these variables are not used as matching variables.

One may wonder to what extent our results related to differences in post-investment financial and innovative performance between ECF firms with a direct shareholder structure (funded through Crowdcube) and those with a nominee structure (funded through Seedrs) will reflect differences in shareholder structures adopted by these platforms or rather reflect other potential platform effects. Two broad platform effects may be at work: selection and influence. With respect to platform selection effects (i.e., different platforms select or attract different firms), several measures ensure that these effects should be limited. First, we use a matched sample design (which minimizes the impact of selection effects - see also Puri and Zarutskie, 2012). Second, given that all projects were funded by the crowd on either one of the platforms, this entails that the crowd collectively assessed all projects as "investment ready". Thus, our results will most likely reflect differences in platform influence effects between Crowdcube and Seedrs. Ultimately, these platform influence effects reflect 
differences in the shareholder structure employed by both platforms. Indeed, by definition, Crowdcube is no longer involved in the firms financed through its platform post-investment. Rather, the members of the crowd act as individual, direct shareholders. On Seedrs, however, the platform still influences the firms financed through its platform post-investment, because the platform remains active as a nominee.

\section{Variable Definitions}

This study investigates the post-investment evolution of ECF and matched NECF firms. In this regard, we are primarily interested in the evolution of financial and innovative performance.

We use two variables in our analysis to measure the evolution of financial performance: profitability and failure rate. A key aspect of a firm's financial performance is its profitability, which we measure as the profit or loss of the year scaled by total assets.

Davidsson et al. (2009) illustrate that early profitability in firms is important to enable future profitable growth. We further measure whether firms fail. We track the failure rate and examine whether the timing of failure differs. Avoiding failure is a key concern for entrepreneurs and investors in early-stage firms (Damodaran, 2009).

To capture innovative performance, we use the intangible assets ratio and the number of patent applications. First, the intangible assets ratio is measured as intangible fixed assets (including capitalized R\&D expenses and the value of patents, trademarks, and brands) scaled by total assets (Michaelas et al., 1999). ${ }^{15}$ Second, we use the number of patent applications. We further differentiate between the number of UK and non-UK patent applications and investigate the number of granted patents. ${ }^{16}$

As highlighted before, we further distinguish between ECF firms with a direct shareholder structure and those with a nominee structure. In a direct shareholder structure, each equity crowd investor becomes a legal shareholder of the firm she/he decides to support. 
This structure has been adopted by Crowdcube (with a few exceptions). In a nominee structure, equity crowdfunding platforms hold and manage the shares invested in ECF firms on behalf of the crowd investors. The nominee (the platform) is the legal shareholder in the firm's shareholder register. This structure has been adopted by Seedrs.

\section{RESULTS}

\section{Equity Crowdfunding and Firm Performance}

Table 1 provides basic descriptive statistics on the matching variables for the ECF firms and matched NECF firms in the year of their equity issue (i.e. year $=0$ ). We find no significant differences in industry distribution, firm age, firm size, firm performance and intangible assets ratio (all $\mathrm{p}>0.10$ ) between both groups of firms, thereby confirming the validity of our matching procedure. Firms are primarily active in "other industries", "finance", and "wholesale and retail". ${ }^{17}$ The median age of both ECF and NECF firms equals 2 years. For both ECF and NECF firms the average (median) amount of total assets equals approximately $£ 100,000$ ( $£ 56,000)$. The average ECF and matched NECF firms are making large losses (ECF: -24\%; NECF -14\%), while the median ECF and NECF firms are break-even (ECF: $2 \%$; NECF $0 \%$ ). This finding is consistent with recent research that shows that firms that lack internal funds are more likely to search for equity crowdfunding (Walthoff-Borm et al., 2018). On average, some $3 \%$ to $4 \%$ of the assets of ECF firms and NECF firms are intangible assets.

In Table 2, we start by exploring the financial performance of ECF and matched NECF firms. We focus on two dimensions of financial performance and first discuss firm profitability before discussing firm failure. Post-campaign, there are no significant differences in firm profitability between the average (median) ECF and NECF firm (all $p$ > 
0.10). Both the average ECF firm and matched NECF firm keep accumulating significant losses over time. The median ECF and NECF firms are break-even, with a jump in median profitability for ECF firms in the year after the campaign. The distribution of quartiles of firm profitability, however, provides interesting insights. On the one hand, the 'best' performing ECF firms (Q3) realize notably higher profits than the 'best' performing NECF firms over time. On the other hand, the 'worst' performing ECF firms (Q1) realize dramatically larger losses than the 'worst' performing NECF firms over time. ${ }^{18}$ These findings suggest that while some ECF firms perform particularly well, other perform particularly poorly.

The above results on firm profitability should be interpreted with care because firms are included as long as their relevant data are available (and failed firms will no longer report financial accounts). The failure rate is significantly higher among ECF firms than NECF firms. The failure rate by December 2017 is $17 \%$ for ECF firms and $2 \%$ for matched NECF firms. Thus, the failure rate for ECF firms is 8.5 times higher than for matched NECF firms. Combined, these findings provide no support for hypothesis H1a.

In Table 2, we further explore the innovative performance of ECF and matched NECF firms. We focus on two dimensions of innovative performance and first discuss the intangible assets ratio before discussing patent data. Post-campaign differences in intangible assets ratios between ECF and NECF firms are not statistically significant (all p > 0.10). Moreover, pre-campaign, there are no differences in mean patent applications between ECF and NECF firms. However, from the year of the campaign and in post-campaign years, ECF firms generally exhibit significantly more patent applications than NECF firms. By December 2017, 17 ECF firms applied for patents compared to only 5 NECF firms. Moreover, 8 ECF firms are granted one or more patents compared to only 2 NECF firms. Thus, 3.4 times more ECF firms have patent applications, and 4 times more ECF firms have patents granted 
relative to matched NECF firms. These findings provide supporting evidence for hypothesis H1b.

\section{Shareholder Structures (Direct vs. Nominee) and Firm Performance}

Table 3 provides basic descriptive statistics on the industry distribution, firm age, firm size, firm performance and intangible assets ratio of the ECF firms in the year of their first campaign (i.e. year $=0$ ), where we make a distinction between ECF firms with a direct shareholder structure and those with a nominee structure. Differences between both groups are not significant ( $\mathrm{p}>0.10$ ). In both groups, firms are mostly active in "other industries", "finance", and "wholesale and retail" as described above. For both groups, the median firm is 2 years old and has just above $£ 100,000$ in total assets. Taken together, these results confirm the validity of our matching process.

Although we did not match on firm performance and intangible assets ratio when differentiating between distinct types of ECF firms, due to the smaller subsamples, there are no substantial differences in terms of these variables. The average (median) profitability is very negative for both ECF firms financed through a direct shareholder structure and those financed through a nominee structure. ECF firms with a nominee structure make smaller losses than those with a direct shareholder structure, but the difference is only marginally significant $(p=0.07)$. In terms of intangible assets ratio, the average ECF firm with a direct shareholder structure has $8 \%$ of intangible assets to total assets; those with a nominee structure have $5 \%$ of intangible assets to total assets. This difference is not significant ( $\mathrm{p}>$ $0.10)$.

In Table 4, we compare the financial and innovative performance of ECF firms with a direct shareholder structure and those with a nominee structure. With regard to financial performance, 2 years after the campaign, average (median) losses are substantially larger for 
ECF firms with a direct shareholder structure relative to those with a nominee structure $(\mathrm{p}<$ 0.10 and better). When we look at the cumulative failure ratio up to December 2017, we see a difference between ECF firms with a direct shareholder structure (12\%) and those with a nominee structure $(17 \%)$, although this difference is statistically insignificant $(\mathrm{p}>0.10)$. This finding, combined with the significantly worse profitability in year 2 of ECF firms with a direct shareholder structure (see especially the low performance at Q1) suggests that many of these firms are in financial distress (but did not fail yet). Combined, these findings provide supporting evidence for hypothesis $\mathrm{H} 2 \mathrm{a}$.

For the innovative performance, we find that while ECF firms with a direct shareholder structure have significantly higher average intangible assets ratios in year -1 compared to ECF firms with a nominee structure, this result tends to reverse in year 2. However, contrary to our first observation and our expectations, ECF firms with a direct shareholder structure exhibit a stronger patent application activity than ECF firms with a nominee structure. This difference is already evident before the campaign, but the difference further widens over time. Indeed, from the year of the campaign up to December 2017, ECF firms with a direct shareholder structure have 90 new patent applications relative to 18 new patent applications for those with a nominee structure. Finally, it is interesting to note that the patenting activity of ECF firms with a direct shareholder structure is oriented more internationally (i.e. non-UK), while for ECF firms with a nominee structure almost all patent application activity relates to UK patents. Overall, these findings provide no support for hypothesis $\mathrm{H} 2 \mathrm{~b}$.

\section{Robustness Tests}

To assess the robustness of our results we perform several additional tests. First, to test hypotheses H1a and H1b, we construct a matched sample of NECF firms based on a sample 
of firms that raised capital, but did not do so through equity crowdfunding. An alternative comparison can be made with a matched sample of NECF firms based on a random sample of firms (that excludes ECF firms, but is representative of the average firm in the UK economy). The latter approach has been common, for instance, in studies that compare venture capitalbacked and non-venture capital-backed firms (Puri \& Zarutskie, 2012). We use this alternative matching group to demonstrate that our results are independent of the chosen matching group. ${ }^{19}$ For each ECF firm, we select a NECF firm from the random sample that is similar in terms of industry, firm age, firm size, firm performance and intangible assets ratio. Our results (detailed tables are not reported due to space considerations) remain qualitatively similar and are even stronger. More specifically, we fail to find a difference in the profitability of ECF firms and NECF firms but ECF firms have significantly higher failure rates than NECF firms. Thus, we again fail to find support for hypothesis H1a. Next, we find that post-campaign, ECF firms have significantly larger intangible assets ratios than NECF firms. Moreover, ECF firms exhibit significantly higher rates of patent applications than NECF firms. Combined, this evidence again supports hypothesis $\mathrm{H} 1 \mathrm{~b}$.

Second, to test hypotheses $\mathrm{H} 2 \mathrm{a}$ and $\mathrm{H} 2 \mathrm{~b}$, we also test for differences between ECF firms financed through a direct or nominee shareholder structure before February 2015. We do so to address the concern that some entrepreneurs could choose between a direct and nominee shareholder structure on Crowdcube after February 2015. We find further support for the same hypotheses as in our primary results; that is, ECF firms financed through a nominee shareholder structure make smaller losses, yet ECF firms through a direct shareholder structure have more new patent applications, including foreign patent applications. $^{20}$

\section{DISCUSSION AND CONCLUSION}


In this paper, we examine the relationship between equity crowdfunding, shareholder structures, and firm performance. For this purpose, we use a longitudinal dataset of UK ECF firms that we track from the year before the equity crowdfunding campaign up to two years thereafter and a matched sample of NECF firms that raised other sources of capital. Several important findings emerge from our study.

First, we fail to find a difference in post-campaign profitability between ECF and NECF firms, after matching ECF and NECF firms on profitability (among other variables) in the year of raising capital. Interestingly, on average, ECF firms generate large losses in the year of their campaign (and so do the matched NECF firms, unsurprisingly). Contrary to our expectations, however, ECF firms do exhibit significantly higher failure rates than NECF firms. Combined, these findings suggest that despite the unique selection mechanisms embodied in equity crowdfunding platforms (i.e. the wisdom of the crowd), important adverse selection issues remain in equity crowdfunding markets. However, we do find that ECF firms outperform matched NECF firms on innovative performance. Specifically, ECF firms exhibit stronger patenting application activity relative to matched NECF firms. Thus, equity crowdfunding platforms also serve as a catalyst for innovative activities.

Our findings that ECF firms have a higher patenting activity, but also exhibit higher failure rates than NECF firms, do neither imply that patents are "bad" and ECF firms make wrong managerial decisions, nor that patents can be interpreted as a "bad" signal to crowd investors. Our findings do suggest that the average ECF firm exhibits higher patenting activity relative to the average NECF firm, despite the fact that more ECF firms fail and those failed ECF firms can by definition no longer apply for patents. Moreover, it is important to acknowledge that our study focuses on the short-term outcomes of ECF and NECF firms. As the equity crowdfunding market develops, additional insights might emerge on the longer-term outcomes. 
Second, we consider two different shareholder structures in equity crowdfunding (i.e. direct and nominee shareholder structures), which allow us to study the influence of shareholder dispersion on firm performance in equity crowdfunding. ECF firms financed through a nominee structure make smaller losses relative to matched ECF financed through a direct shareholder structure. These findings provide evidence that nominee shareholder structures in equity crowdfunding are positively associated with firm financial performance, which may be a consequence of the increased power and incentives of nominees to monitor management and the lower coordination costs. For firm innovation, however, we find that ECF firms with direct shareholder structures focus more on patenting and have more international patent applications relative to their matches with nominee structures, which may be a consequence of selection but also the increased feeling of belonging of direct shareholders and thus their increased input in the innovation trajectory of firms. Overall, these findings provide nuanced evidence on the role of ownership dispersion in equity crowdfunding.

\section{Academic Contributions}

This paper makes several academic contributions. First, we contribute to the entrepreneurial finance literature. While many studies have focused on traditional outside sources of equity financing (such as venture capitalists and angels), we still lack research on new alternative sources of financing (Cumming \& Vismara, 2017) and equity crowdfunding in particular (Vismara, 2016, 2018). Still, equity crowdfunding is fundamentally different from traditional equity financing. While equity crowdfunding relies on the wisdom of the crowd, professional investors rely on detailed due diligence to select firms. Moreover, crowd investors are typically less involved in firms relative to traditional equity investors, but they do provide other non-financial benefits, such as feedback and market validation. We find a mixed set of results for ECF firms; their financial performance is generally worse, while their innovative 
performance is better than that of NECF firms. Overall, we have provided first-time evidence on the performance of ECF firms using a matched control sample.

Second, we provide new insights on the role of governance structures in equity crowdfunding. Our limited understanding of corporate governance in equity crowdfunding is unfortunate considering that raising equity crowdfunding may represent a double-edged sword. Indeed, the wisdom of the crowd represents a core aspect of equity crowdfunding, but it may involve some challenges, such as agency and coordination costs related with having many potential crowd investors, that need to be considered. Understanding the role of direct shareholder and nominee structures in equity crowdfunding, and particularly how they affect firm performance is hence important. We further provide first-time evidence on how governance structures may affect ECF firms. We provide a nuanced picture, suggesting that both direct shareholder and nominee structures have their advantages and disadvantages for firm financial and innovative performance, respectively.

\section{Limitations and Avenues for Future Research}

As with any research, our study has limitations that could serve as important starting points for future research in the equity crowdfunding domain.

First, while our matched sample approach allows us to make claims about differences between ECF and NECF firms (and between ECF firms financed through a direct ownership structure and ECF firms financed through a nominee structure) that are similar on specific observable characteristics, we cannot perfectly distinguish selection from causation. Still, our approach is similar to the state-of-the-art in more mature fields of research such as venture capital (see for instance Puri \& Zarutskie, 2012; if anything, we use an even stricter set of matching variables). Nevertheless, as more data becomes available in the equity crowdfunding context, future research that uses other econometric techniques to disentangle selection from causation in equity crowdfunding markets would be valuable. 
Second, we have compared ECF firms financed through Crowdcube that uses a direct shareholder structure and ECF firms financed through Seedrs that uses a nominee structure. However, equity crowdfunding platforms are also characterized by other differences in terms of platform design and governance (Hornuf \& Schwienbacher, 2018). Future research that examines a broader set of platforms and differences in platform design can again provide valuable contributions to the literature.

Third, our study has used a maximum of two years of post-campaign data. Future studies that use a longer timeframe to examine the effects of equity crowdfunding are definitely warranted. However, for now, we report primarily on the short-term effects due to a lack of data, given the recent emergence of the equity crowdfunding market. When more data becomes available scholars will be able to provide more insights into the longer-term effects of raising crowdfunding.

Finally, much research in equity crowdfunding has focused on one specific context, the UK. With Brexit, it will be interesting to monitor the evolution of the UK crowdfunding market. Moreover, differences in formal institutions (including equity crowdfunding regulations) and informal institutions (such as cultural differences) call for more research on how ECF firms evolve in different countries.

\section{Practical Contributions}

Our study has important implications for policymakers. Supported by tax incentives, equity crowdfunding has grown to be an important financing alternative for entrepreneurial firms that struggle to access mainstream finance (Walthoff-Borm et al., 2018). In the wake of a number of recent anecdotal equity crowdfunding successes and failures, it is important to expand our broader understanding of the relationship between equity crowdfunding, shareholder structures, and firm performance. This research suggests that adverse selection issues remain important in the equity crowdfunding context, but that equity crowdfunding 
eventually also serves as a catalyst for firm innovation activities. Crowd investor protection against adverse selection issues will be important to ensure the sustainability of the equity crowdfunding market (e.g., Akerlof \& Shiller, 2015). For policymakers, it also remains important to further monitor the performance of those firms that access equity crowdfunding markets in order to take timely corrective actions when equity crowdfunding markets fail to deliver their promise of providing access to finance for viable businesses.

Also for equity crowdfunding platforms, our findings provide important insights. It is troublesome that failure rates of ECF firms are multiple times higher than those of NECF firms. While failure is commonplace in the entrepreneurial setting, it suggests that platforms can step up their due diligence efforts to further reduce such failures. Moreover, while many platforms already actively inform their visitors of the riskiness of equity crowd investing, they can further highlight best practices that amateur investors can pursue to minimize risks (such as taking a portfolio approach).

For entrepreneurs and crowd investors, our study provides new evidence on how ECF firms perform in the short term. Our results suggest that raising equity crowdfunding is only a first step for entrepreneurs, but is often insufficient to ensure firm survival in the face of intense evolutionary pressures. Fortunately, within the group of surviving ECF firms, some also exhibit high profitability. However, it remains the question whether crowd investors will eventually be able to realize gains on their investments at the time of exit.

\section{Concluding Note}

Using data from two UK crowdfunding platforms, we find that ECF firms have a higher failure rate than matched NECF firms. However, ECF firms also have more patent applications than matched NECF firms. Within the group of ECF firms, we find that ECF firms financed through a nominee structure make smaller losses, while ECF firms financed through a direct shareholder structure have more patent applications, including foreign patent 
applications. These findings provide new insights into the performance of ECF firms and the differences in performance between ECF firms with dispersed and concentrated crowd shareholders.

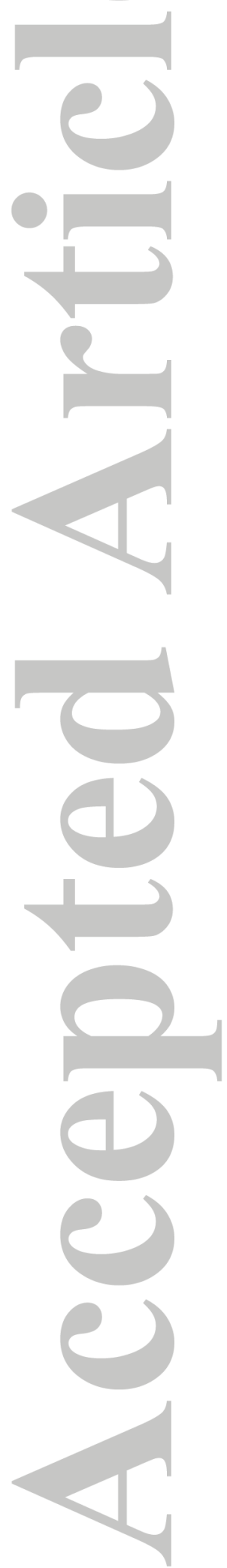




\section{NOTES}

1. Equity crowdfunding refers to "a method of financing, whereby an entrepreneur sells a specified amount of equity or bond-like shares in a company to a group of (small) investors through an open call for funding on Internet-based platforms" (Ahlers et al., 2015: 958).

2. Drover et al. (2017) use experimental data to investigate how different forms of crowdfunding influence venture capitalist's screening decisions; Hornuf and Schmitt (2017) examine failure rates of equity crowdfunded firms in Germany and the UK; Signori and Vismara (2018) focus on failures, follow-on financing, and M\&A exits in equity crowdfunding.

3. For our primary analysis, we have matched each ECF firm with a similar firm that did not raise equity crowdfunding (i.e. NECF firm) but raised capital from other sources. These other sources of capital generally include entrepreneurs themselves, friends or family, but can also include venture capital and angel investors. In a robustness test, we have also matched each ECF firm with a similar firm from a random sample of firms that did not attract crowdfunding. We describe our matching procedures in more detail in the Method section below.

4. Others, however, have argued that the wisdom of the crowd is unlikely to hold in equity crowdfunding (e.g., Isenberg, 2012). They point out that early-stage investment is intrinsically complicated and that amateur crowd investors do not have the skills required to distinguish a good from a bad venture. Moreover, they argue that herding behavior may impair the crowd's judgment. Despite these counterarguments, Mollick (2014) and Cumming et al. (2016) illustrate that crowdfunding has significant fraud immunity and that sharing information on crowdfunding platforms serves to self-correct the "foolishness" of the crowd (Hood, 2014).

5. This common wisdom is also confirmed in our sample of NECF firms that raise other sources of capital. Specifically, only $1 \%$ of NECF firms raised venture capital.

6. It may seem that professional investors could easily exploit the crowd; however, such behavior could have important repercussions for the professional investors. Specifically, legitimate grounds to be unhappy or dissatisfied may push the crowd to take their "story" to the Internet or the media. This may not only impact the crowdfunded firm's reputation but also the reputation of the professional investor.

7. Many of the rights and protections are found in the Companies Act 2006, which is a primary source of law for companies in the UK. In a number of places, the protections are subject to modifications in companies' articles of association, so the 2006 Act must always be considered alongside the statutes of the company. 
8. See ss. 303-306 Companies Act 2006.

9. See s. 994 of the Companies Act 2006.

10. It is important to note, however, that Crowdcube more recently made changes in the possible shareholder structures adopted on its platform. These changes provide entrepreneurs with more flexibility to choose between a direct shareholder structure and a nominee structure. More specifically, from the launch of Crowdcube until February 2015, by selecting Crowdcube as their crowdfunding platform, entrepreneurs automatically selected a direct shareholder structure as well. After February 2015, Crowdcube provided nominee services as well, but only for firms raising over $£ 250,000$. For this service, Crowdcube charges additional fees. Crowdcube still favors a direct shareholder structure, however. But dependent on the investment size, entrepreneurs can now choose between the direct or nominee shareholder structure on Crowdcube. Still, in 2015, we are aware of only 2 cases that adopted a nominee structure on Crowdcube and these cases are not included in our study. By selecting Seedrs as their crowdfunding platform, entrepreneurs themselves select a nominee shareholder structure.

11. See, for example: http://www.whatinvestment.co.uk/clash-of-the-crowdfunding-platformscrowdcube-and-seedrs-debate-which-model-is-best-for-investors-2399532/

12. The Internet archive Wayback Machine enables scholars to capture, manage and search collections of digital content. It hence allows scholars to go back in time and capture historical data from websites.

13. Matching on firm age controls for two effects: (a) it ensures that the firms are founded in the same year and (b) it ensures that firms raised crowdfunding in the same year. We could also match on the time of the crowdfunding campaign (+/- 6 months) but this criterion by itself would imply that these firms could have a different age at the time of the campaign (and a firm that is 1 versus 10 years old is also very different, albeit raising crowdfunding in the same month). We could further extend this approach by then also adding another matching variable: firm age. However, adding more matching variables by definition decreases fit on the other matching variables (industry, size). Our approach also ensures consistency between the first part of our paper (where we compare ECF and NECF firms and the NECF firms do not have a crowdfunding campaign date by definition) and the second part of our paper (where we focus on differences within the group of ECF firms).

14. The sum of the number of ECF firms financed through a direct shareholder structure and a nominee structure in this sample is higher compared to the total number of ECF firms in our previous sample. There are several reasons for this difference. First, for our second matched sample, we started our matching approach again from the full sample of ECF firms. In the 
previous matched sample, for some ECF firms, we did not find a good match to a NECF firms. These ECF firms were hence dropped. Second, we use several ECF firms with a nominee structure multiple times as a match for distinct ECF firms financed through a direct shareholder structure. This procedure allows for decreasing bias (Abadie \& Imbens, 2012) because "control" firms that look similar to many "treated" firms can be used multiple times.

15. UK accounting standards allow firms to capitalize the R\&D expenses as intangible fixed assets; or maintain the policy to write the R\&D costs off to the profit and loss (Collings, 2015). This flexibility obviously entails a shortcoming of the intangible assets ratio. Still, the validity of this measure has been established in previous research (e.g., Degryse et al., 2012). Moreover, we supplement the intangible assets ratio with alternative innovation measures (i.e. patent applications).

16. We also looked at patent citations and cited patents. However, patent citations and cited patents are extremely rare for our samples. Indeed, firms first need to apply for patents before they get granted (several years later) and can get cited. Accordingly, we focus on the number of patent applications as one measure for innovative performance.

17. The "other industries" category includes goods- and services producing activities and business support service activities. The "finance" category includes activities auxiliary to the finance industry; data processing, hosting and related activities; and computer programming, consultancy and related activities. Classification is based on the Fama and French industry classification, which is developed to link existing SIC groups based on 4-digits to various industries.

18. Still, the S.D. of profitability in years 1-2 is lower among ECF firms. This finding is due to one extreme observation in the NECF group (with a low performance of -4.42 and -6.73 respectively). Because, the S.D. is more subject to such extreme observations than an analysis of the quartiles, we refrain from drawing strong conclusions from the S.D. It is also worth noting the strikingly low mean value for ECF firms in year -1, which is also due to some "extreme" observations. For example, the total assets of one such observation was $£ 4,320$ in year -1 . Therefore, the relatively large losses of this firm ( $£-107,855)$ relative to its small amount of assets resulted in a highly negative profitability ratio. Nonetheless, when removing these few observations, the mean profitability of ECF firms in year -1 is still significantly different from the mean profitability of NECF (Mean ECF $=-0.814, p=0.002$ ).

19. These different approaches have no impact on our tests within the group of ECF firms (i.e. hypotheses $\mathrm{H} 2 \mathrm{a}$ and $\mathrm{H} 2 \mathrm{~b}$ ).

20. Detailed results of these tests are not reported here but are available on request. 


\section{REFERENCES}

Abadie, A., \& Imbens, G. (2012). Bias-corrected matching estimators for average treatment effects. Journal of Business \& Economic Statistics, 29(1), 1-11.

Ahlers, G., Cumming, D., Günther, C., \& Schweizer, D. (2015). Signaling in equity crowdfunding. Entrepreneurship Theory and Practice, 39(4), 955-980.

Akerlof, G., \& Shiller, R. (2015). Phishing for phools: The economics of manipulation and deception. Princeton University Press.

Allison, T., Davis, B., Short, J., \& Webb, J. (2015). Crowdfunding in a prosocial microlending environment: Examining the role of intrinsic versus extrinsic cues. Entrepreneurship Theory and Practice, 39(1), 53-73.

Allison, T., Davis, B., Webb, J., \& Short, J. (2017). Persuasion in crowdfunding: An elaboration likelihood model of crowdfunding performance. Journal of Business Venturing, 32(6), 707-725.

Barry, C., Muscarella, C., Peavy, J., \& Vetsuypens, M. (1990). The role of venture capital in the creation of public companies: Evidence from the going-public process. Journal of Financial Economics, 27(2), 447-471.

Belleflamme, P., Lambert, T., \& Schwienbacher, A. (2014). Crowdfunding: Tapping the right crowd. Journal of Business Venturing, 29(5), 585-609.

Bellavitis, C., Filatotchev, I., Kamuriwo, D., \& Vanacker, T. (2017). Entrepreneurial finance: New frontiers of research and practice. Venture Capital, 19(1), 1-16.

Berger, A., \& Udell, G. (1998). The economics of small business finance: The roles of private equity and debt markets in the financial growth cycle. Journal of Banking \& Finance, 22(6), 613-673.

Bertoni, F., Colombo, M., \& Quas, A. (2015). The patterns of venture capital investment in Europe. Small Business Economics, 45(3), 543-560.

Block, J., Colombo, M., Cumming, D., \& Vismara, S. (2018a). New players in entrepreneurial finance and why they are there. Small Business Economics, 50(2), 239250.

Block, J., Hornuf, L., \& Moritz, A. (2018b). Which updates during an equity crowdfunding campaign increase crowd participation? Small Business Economics, 50(1), 3-27.

Block, J., \& Sandner, P. (2009). What is the effect of the financial crisis on venture capital financing? Empirical evidence from US Internet start-ups. Venture Capital, 11(4), 295309.

Brav, O. (2009). Access to capital, capital structure, and the funding of the firm. Journal of Finance, 64(1), 263-308.

Bruton, G., Khavul, S., Siegel, D., \& Wright, M. (2015). New financial alternatives in seeding entrepreneurship: Microfinance, crowdfunding, and peer-to-peer innovations. Entrepreneurship Theory and Practice, 39(1), 9-26. 
Butticè, V., Colombo, M., \& Wright, M. (2017). Serial crowdfunding, social capital, and project success. Entrepreneurship Theory and Practice, 41(2), 183-207.

Carpenter, R. E., \& Petersen, B. C. (2002). Is the growth of small firms constrained by internal finance? The Review of Economics and Statistics, 84(2), 298-309.

Cassar, G. (2004). The financing of business start-ups. Journal of Business Venturing, 19(2), 261-283.

Chan, R., \& Parhankangas, A. (2017). Crowdfunding innovative ideas: How incremental and radical innovativeness influence funding outcomes. Entrepreneurship Theory and Practice, 41(2), 237-263.

Chang, W., \& Taylor, S. (2016). The effectiveness of customer participation in new product development: A meta-analysis. Journal of Marketing, 80(1), 47-64.

Collewaert, V., Manigart, S., \& Aernoudt, R. (2010). Assessment of government funding of business angel networks in Flanders. Regional Studies, 44(1), 119-130.

Collings, S. (2015). Intangible assets, in interpretation and application of UK GAAP: For accounting periods commencing on or after 1 January 2015, John Wiley \& Sons, Ltd, Chichester, UK.

Colombo, M., Franzoni, C., \& Rossi-Lamastra, C. (2015). Internal social capital and the attraction of early contributions in crowdfunding. Entrepreneurship Theory and Practice, 39(1), 75-100.

Colombo, M., \& Shafi, K. (2016). When does reward-based crowdfunding help firms obtain external financing? SSRN working paper, DOI: 10.2139/ssrn.2785538.

Cosh, A., Cumming, D., \& Hughes, A. (2009). Outside entrepreneurial capital. The Economic Journal, 119(540), 1494-1533.

Courtney, C., Dutta, S., \& Li, Y. (2017). Resolving information asymmetry: Signaling, endorsement, and crowdfunding success. Entrepreneurship Theory and Practice, 41(2), 265-290.

Cowling, M., Liu, W., \& Ledger, A. (2012). Small business financing in the UK before and during the current financial crisis. International Small Business Journal, 30(7), 778-800.

Cumming, D., Hornuf, L., Karami, M., \& Schweizer, D. (2016). Disentangling crowdfunding from fraudfunding. SSRN working paper, DOI: 10.2139/ssrn.2828919.

Cumming, D., \& Zhang, Y. (2018). Are crowdfunding platforms active and effective intermediaries? SSRN working paper. DOI: 10.2139/ssrn.2882026.

Cumming, D., Meoli., M. \& Vismara, S. (2017). Investors' choice between cash and voting rights: evidence from dual-class equity crowdfunding. Paper presented at the 2nd Entrepreneurial Finance Conference (6-7 July 2017, Ghent).

Cumming, D., \& Vismara, S. (2017). De-segmenting research in entrepreneurial finance. Venture Capital, 19(1-2), 17-27. 
Cumming, D., \& Wright, M. (2017). Entrepreneurial finance in a changing landscape. Keynote presentation at the 2nd Entrepreneurial Finance Conference (6-7 July 2017, Ghent).

Dalton, D., Daily, C., Certo, S., \& Roengpitya, R. (2003). Meta-analyses of financial performance and equity: Fusion or confusion? Academy of Management Journal, 46(1), $13-26$.

Damodaran, A. (2009). The dark side of valuation: Valuing young, distressed, and complex businesses (2nd ed.). FT Press.

Davidsson, P., Steffens, P., \& Fitzsimmons, J. (2009). Growing profitable or growing for profits: Putting the horse in front of the car? Journal of Business Venturing, 24(4), 388406.

Davis, B., Hmieleski, K., Webb, J., \& Coombs, J. (2017). Funders' positive affective reactions to entrepreneurs' crowdfunding pitches: The influence of perceived product creativity and entrepreneurial passion. Journal of Business Venturing, 32(1), 90-106.

Degryse, H., de Goeij, P., \& Kappert, P. (2012). The impact of firm and industry characteristics on small firms' capital structure. Small Business Economics, 38(4), 431447.

Dharwadkar, B., George, G., \& Brandes, P. (2000). Privatization in emerging economies: An agency theory perspective. Academy of Management Review, 25(3), 650-669.

Drover, W., Wood, M., \& Zacharakis, A. (2017). Attributes of angel and crowdfunded investments as determinants of VC screening decisions. Entrepreneurship Theory and Practice, 41(3), 323-347.

Filatotchev, I., \& Wright, M. (2017). Methodological issues in governance research: An editor's perspective. Corporate Governance: An International Review, 25(6), 454-460.

Fleming, L., \& Sorenson, O. (2016). Financing by and for the Masses. California Management Review, 58(2), 5-19.

Giudici, G., Guerini, M., \& Rossi-Lamastra, C. (2018). Reward-based crowdfunding of entrepreneurial projects: the effect of local altruism and localized social capital on proponents' success. Small Business Economics, 50(2), 307-324.

Gompers, P., Kovner, A., \& Lerner, J. (2009). Specialization and success: Evidence from venture capital. Journal of Economics \& Management Strategy, 18(3), 817-844.

Grell, K., Marom, D., Swart, R. (2015). Crowdfunding: the corporate era. Elliott \& Thompson, Ltd., London.

Gruner, K. E., \& Homburg, C. (2000). Does customer interaction enhance new product success? Journal of Business Research, 49(1), 1-14.

Harrison, R. (2013). Crowdfunding and the revitalisation of the early stage risk capital market: catalyst or chimera? Venture Capital, 15(4), 283-287. 
Hart, O. (1995). Corporate governance: Some theory and implications. The Economic Journal, 105(430), 678-689.

Hood, J. (2014). Inefficient market theory: an investment framework based on the foolishness of the crowd. CreateSpace Independent Publishing Platform, North Charleston, South Carolina.

Hornuf, L., \& Schmitt, M. (2017). Equity crowdfunding in Germany and the UK: Follow-up funding and firm survival. Max Planck Institute for Innovation \& Competition Research Paper No. 17-09

Hornuf, L., \& Schwienbacher, A. (2017). Should securities regulation promote equity crowdfunding? Small Business Economics, 49(3), 579-593.

Hornuf, L., \& Schwienbacher, A. (2018). Internet-based entrepreneurial finance: Lessons from Germany. California Management Review, 60(2), 150-175.

Isenberg, D. (2012). The road to crowdfunding hell. Harvard Business Review, April 23 (assessed July 1, 2017).

Iyer, R., Khwaja, A. I., Luttmer, E. F., \& Shue, K. (2015). Screening peers softly: Inferring the quality of small borrowers. Management Science, 62(6), 1554-1577

Jensen, M., \& Meckling, W. (1976). Theory of the firm: managerial behaviour, agency costs and owhership structure. Journal of Financial Economics, 3(4), 305-360.

Joshi, A., \& Sharma, S. (2004). Customer knowledge development: Antecedents and impact on new product performance. Journal of Marketing, 68(4), 47-59.

King, G., \& Nielsen, R. (2016). Why propensity scores should not be used for matching. Working paper, Harvard University.

Kumar, P., \& Zattoni, A. (2017). Advancing the literature on ownership structure and corporate governance. Corporate Governance: An International Review, 25(1), 2-3.

Lasfer, M. A. (1997). On the motivation for paying scrip dividends. Financial Management, 62-80.

Lovegod, B. (2016). Hold my assets. The Fintech Times, April 7 (assessed July 1, 2017).

Lovelock, C., \& Young, R. (1979). Look to consumers to increase productivity. Harvard Business Review, 57(3), 168-178.

Mahr, D., Lievens A., \& Blazevic V. (2014). The value of customer cocreated knowledge during the innovation process. Journal of Product Innovation Management, 31 (3), 599615.

Manigart, S., Baeyens, K., \& Van Hyfte, W. (2002). The survival of venture capital backed companies. Venture Capital, 4(2), 103-124.

Michaelas, N., Chittenden, F., \& Poutziouris, P. (1999). Financial policy and capital structure choice in UK SMEs: Empirical evidence from company panel data. Small Business Economics, 12(2), 113-130. 
Mollick, E. (2014). The dynamics of crowdfunding: An exploratory study. Journal of Business Venturing, 29(1), 1-16.

Mollick, E., \& Kuppuswamy, V. (2014). After the campaign: Outcomes of crowdfunding, Working Paper, Wharton, University of Pennsylvania.

Mollick, E., \& Nanda, R. (2016). Wisdom or madness. Comparing crowds with expert evaluation in funding the arts. Management Science, 62(6), 1533-1553.

Mollick, E., \& Robb, A. (2016). Democratizing innovation and capital access. California Management Review, 58(2), 72-87.

Prahalad, C., \& Ramaswamy, V. (2004). Co-creation experiences: The next practice in value creation. Journal of Interactive Marketing, 18(3), 5-14.

Puri, M., \& Zarutskie, R. (2012). On the life cycle dynamics of venture-capital-and non-venture-capital-financed firms. Journal of Finance, 67(6), 2247-2293.

Ralcheva, A., \& Roosenboom, P. (2016). On the road to success in equity crowdfunding. SSRN working paper, DOI: 10.2139/ssrn.2727742.

Rosenbusch, N., Brinckmann, J., \& Müller, V. (2013). Does acquiring venture capital pay off for the funded firms? A meta-analysis on the relationship between venture capital investment and funded firm financial performance. Journal of Business Venturing, 28(3), 335-353.

Sapienza, H., Manigart, S., \& Vermeir, W. (1996). Venture capitalist governance and value added in four countries. Journal of Business Venturing, 11(6), 439-469.

Sapienza, H., Korsgaard, M., \& Forbes, D. (2003). The self-determination motive and entrepreneurs' choice of financing. Cognitive approaches to entrepreneurship research, 6 , 105-138.

Schwienbacher, A., \& Larralde, B. (2012). Crowdfunding of small entrepreneurial ventures. Handbook of entrepreneurial finance, In Cummings, D. (ed.). The Oxford Handbook of Entrepreneurial Finance. Oxford University Press: Oxford, pp. 369-91.

Shleifer, A., \& Vishny, R. (1997). A survey of corporate governance. Journal of Finance, 52(2), 737-783.

Short, J., Ketchen, D., McKenny, A., Allison, T., \& Ireland, R. (2017). Research on crowdfunding: Reviewing the (very recent) past and celebrating the present. Entrepreneurship Theory and Practice, 41(2), 149-160.

Signori, A., \& Vismara, S. (2018). Does success bring success? The post-offering lives of equity-crowdfunded firms. Journal of Corporate Finance, DOI: 10.1016/j.jcorpfin.2017.10.018.

Stanko, M., \& Henard, D. (2017). Toward a better understanding of crowdfunding, openness and the consequences for innovation. Research Policy, 46(4), 784-798.

Surowiecki, J. (2005). The wisdom of crowds. Anchor. 
Vanacker, T., \& Manigart, S. (2010). Pecking order and debt capacity considerations for high-growth companies seeking financing. Small Business Economics, 35(1), 53-69.

Vanacker, T., \& Forbes, D. P. (2016). Disentangling the multiple effects of affiliate reputation on resource attraction in new firms. Organization Science, 27(6), 1525-1547.

Vismara, S. (2016). Equity retention and social network theory in equity crowdfunding. Small Business Economics, 46(4), 579-590.

Vismara, S. (2018). Information cascades among investors in equity crowdfunding. Entrepreneurship Theory and Practice, 42(3), 467-497.

Vulkan, N., Åstebro, T., \& Sierra, M. (2016). Equity crowdfunding: A new phenomena. Journal of Business Venturing Insights, 5, 37-49.

Walthoff-Borm, X., Schwienbacher, A., \& Vanacker, T. (2018). Equity crowdfunding. First resort or last resort? Journal of Business Venturing, DOI: 10.1016/j.jbusvent.2018.04.001.

Wang, J., Shih, P., \& Carroll, J. (2015). Revisiting Linus's law: Benefits and challenges of open source software peer review. International Journal of Human-Computer Studies, 77, $52-65$.

Yi, S., Steyvers, M., Lee, M., \& Dry, M. (2012). The wisdom of the crowd in combinatorial problems. Cognitive Science, 36(3), 452-470.

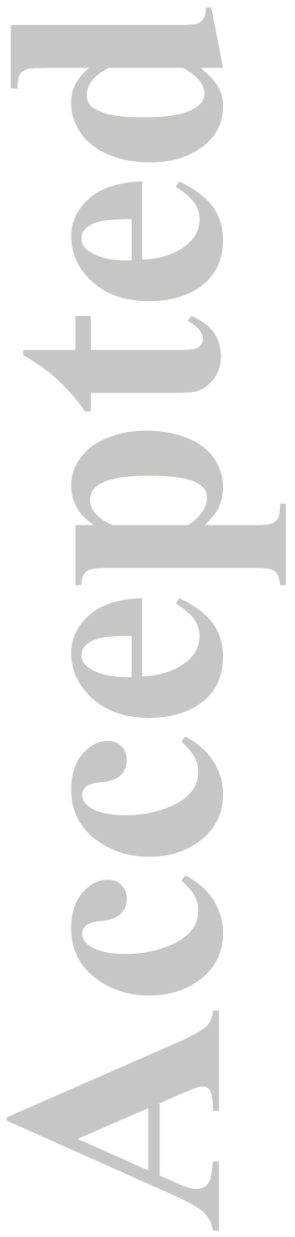


TABLE 1

DESCRIPTIVE STATISTICS OF THE ONE-TO-ONE SAMPLE OF ECF FIRMS AND NECF FIRMS THAT RAISED OTHER SOURCES OF CAPITAL

\begin{tabular}{|c|c|c|c|c|c|c|c|c|c|c|}
\hline \multirow{2}{*}{ Industry distribution } & \multicolumn{2}{|c|}{ Year 0} & \multirow[t]{2}{*}{ Age } & \multicolumn{2}{|c|}{ Year 0} & \multirow[b]{2}{*}{$\mathrm{p}$} & \multirow[t]{2}{*}{ Profitability } & \multicolumn{2}{|c|}{ Year 0} & \multirow[b]{2}{*}{$\mathrm{p}$} \\
\hline & $\mathrm{ECF}$ & NECF & & $\mathrm{ECF}$ & NECF & & & $\mathrm{ECF}$ & NECF & \\
\hline Wholesale, Retail, and Some Services & 0.10 & 0.11 & Median & 2.00 & 2.00 & 0.85 & Median & 0.02 & 0.00 & 0.79 \\
\hline Finance & 0.26 & 0.27 & Mean & 2.18 & 2.21 & 0.83 & Mean & -0.24 & -0.14 & 0.83 \\
\hline Other industries & 0.57 & 0.55 & $\mathrm{SD}$ & 1.56 & 1.59 & & $\mathrm{SD}$ & 1.18 & 1.06 & \\
\hline Manufacturing & 0.02 & 0.02 & Number of firms & 205 & 205 & & Number of firms & 205 & 205 & \\
\hline \multirow{7}{*}{ Consumer Non Durables } & 0.02 & 0.02 & & & & & & & & \\
\hline & & & $\overline{\text { Size }}$ & & & & Intangible assets & & & \\
\hline & & & & $\mathrm{ECF}$ & NECF & $\mathrm{p}$ & ratio & $\mathrm{ECF}$ & NECF & $\mathrm{p}$ \\
\hline & & & Median & 55,208 & 58,294 & 0.33 & Median & $0 \%$ & $0 \%$ & 0.62 \\
\hline & & & Mean & 99,571 & 111,365 & 0.37 & Mean & $3 \%$ & $4 \%$ & 0.37 \\
\hline & & & SD & 127,417 & 137,452 & & $\mathrm{SD}$ & $12 \%$ & $13 \%$ & \\
\hline & & & Number of firms & 205 & 205 & & Number of firms & 205 & 205 & \\
\hline
\end{tabular}

Notes. The sample includes UK entrepreneurial firms that raised equity crowdfunding (ECF firms) between 2012 and 2015 (inclusive) for the first time on Crowdcube or Seedrs. These firms were matched to UK firms that raised other sources of capital in the same year (NECF firms). These other sources of capital include entrepreneurs themselves, friends or family, but can also include venture capital and angel investors. The matching variables include industry, firm age, firm size, profitability and intangible assets ratio. The table shows the industry distribution (Fama and French industry classification) of both samples and the descriptive statistics for firm age (years since founding), firm size (total assets in $£$ ), firm profitability (profit or loss on total assets) and intangible assets ratio (intangible fixed assets on total assets, \%). With respect to the industry distribution: "other industries" includes goods- and services producing activities and business support service activities. We use a cut-off, so that industries representing less than $2 \%$ of the sample are not reported for space considerations.

This article is protected by copyright. All rights reserved. 
TABLE 2

FINANCIAL AND INNOVATIVE PERFORMANCE FOR ECF FIRMS AND MATCHED NECF FIRMS THAT RAISED OTHER SOURCES OF CAPITAL

\begin{tabular}{|c|c|c|c|c|c|c|c|c|c|c|c|c|c|c|c|}
\hline \multirow[t]{2}{*}{ Profitability } & \multicolumn{2}{|c|}{ Year -1} & \multicolumn{3}{|c|}{ Year 0} & \multicolumn{3}{|c|}{ Year 1} & \multicolumn{4}{|c|}{ Year 2} & & & \\
\hline & $\mathrm{ECF}$ & $\mathrm{NECF}$ & Diff & $\mathrm{ECF}$ & NECF & Diff & $\mathrm{ECF}$ & NECF & Diff & $\mathrm{ECF}$ & $\mathrm{NECF}$ & Diff & & & \\
\hline Median & -0.06 & 0.00 & $* * *$ & 0.02 & 0.00 & & 0.14 & 0.00 & & 0.01 & 0.01 & & & & \\
\hline Mean & -2.89 & -0.24 & $* * *$ & -0.24 & -0.14 & & -0.20 & -0.31 & & -0.58 & -0.52 & & & & \\
\hline SD & 6.17 & 1.71 & & 1.18 & 1.06 & & 1.25 & 1.30 & & 1.75 & 1.90 & & & & \\
\hline Q1 $(25 \%)$ & -2.33 & -0.22 & & -0.45 & -0.24 & & -0.53 & -0.26 & & -0.78 & -0.20 & & & & \\
\hline Q3 (75\%) & 0.21 & 0.18 & & 0.59 & 0.51 & & 0.65 & 0.28 & & 0.55 & 0.30 & & & & \\
\hline Number of firms & 138 & 157 & & 205 & 205 & & 176 & 185 & & 76 & 138 & & & & \\
\hline \multirow[t]{2}{*}{ Failures } & \multicolumn{2}{|c|}{ Year - 1} & \multicolumn{3}{|c|}{ Year 0} & \multicolumn{3}{|c|}{ Year 1} & \multicolumn{3}{|c|}{ Year 2} & \multicolumn{4}{|c|}{2017} \\
\hline & $\mathrm{ECF}$ & NECF & Diff & $\mathrm{ECF}$ & $\mathrm{NECF}$ & Diff & $\mathrm{ECF}$ & NECF & Diff & $\mathrm{ECF}$ & $\mathrm{NECF}$ & Diff & $\mathrm{ECF}$ & NECF & Diff \\
\hline Failure rate & 0.00 & 0.00 & & 0.00 & 0.00 & & 0.00 & 0.00 & & 0.08 & 0.00 & $* * *$ & 0.17 & 0.02 & $* * *$ \\
\hline Number of failures & 0 & 0 & & 0 & 0 & & 0 & 0 & & 16 & 1 & & 35 & 4 & \\
\hline Number of firms & 205 & 205 & & 205 & 205 & & 205 & 205 & & 205 & 205 & & 205 & 205 & \\
\hline \multirow[t]{2}{*}{ Intangible assets ratio } & \multicolumn{2}{|c|}{ Year -1} & \multicolumn{3}{|c|}{ Year 0} & \multicolumn{3}{|c|}{ Year 1} & \multirow{2}{*}{\multicolumn{3}{|c|}{$\begin{array}{c}\text { Year 2 } \\
\text { Diff } \mathrm{FCF}\end{array}$}} & & & & \\
\hline & $\mathrm{ECF}$ & NECF & Diff & $\mathrm{ECF}$ & NECF & Diff & $\mathrm{ECF}$ & NECF & & & & Diff & & & \\
\hline Median & $0 \%$ & $0 \%$ & & $0 \%$ & $0 \%$ & & $0 \%$ & $0 \%$ & & $0 \%$ & $0 \%$ & & & & \\
\hline Mean & $3 \%$ & $5 \%$ & & $3 \%$ & $4 \%$ & & $4 \%$ & $5 \%$ & & $6 \%$ & $4 \%$ & & & & \\
\hline SD & $13 \%$ & $18 \%$ & & $12 \%$ & $13 \%$ & & $15 \%$ & $14 \%$ & & $20 \%$ & $12 \%$ & & & & \\
\hline Number of firms & 138 & 157 & & 205 & 205 & & 176 & 185 & & 76 & 138 & & & & \\
\hline \multirow[t]{2}{*}{ Patent Data } & \multicolumn{2}{|c|}{ Year -1} & \multicolumn{3}{|c|}{ Year 0} & \multicolumn{3}{|c|}{ Year 1} & \multicolumn{3}{|c|}{ Year 2} & \multicolumn{4}{|c|}{2017} \\
\hline & $\mathrm{ECF}$ & NECF & Diff & $\mathrm{ECF}$ & NECF & Diff & $\mathrm{ECF}$ & NECF & Diff & $\mathrm{ECF}$ & NECF & Diff & $\mathrm{ECF}$ & NECF & Diff. \\
\hline Median & 0.00 & 0.00 & $*$ & 0.00 & 0.00 & $* *$ & 0.00 & 0.00 & $* *$ & 0.00 & 0.00 & $* *$ & 0.00 & 0.00 & *** \\
\hline Mean & 0.21 & 0.09 & & 0.36 & 0.13 & $\dagger$ & 0.38 & 0.15 & $\dagger$ & 0.38 & 0.15 & $\dagger$ & 0.39 & 0.16 & $\dagger$ \\
\hline $\mathrm{SD}$ & 0.99 & 0.69 & & 1.49 & 1.01 & & 1.60 & 1.07 & & 1.60 & 1.07 & & 1.63 & 1.20 & \\
\hline Number of firms & 205 & 205 & & 205 & 205 & & 205 & 205 & & 205 & 205 & & 205 & 205 & \\
\hline Number of firms with patent applications & & & & & & & & & & & & & 17 & 5 & \\
\hline Number of firms with granted patents & & & & & & & & & & & & & 8 & 2 & \\
\hline Total number of patent applications & & & & & & & & & & & & & 79 & 33 & \\
\hline Total number of patents granted & & & & & & & & & & & & & 10 & 7 & \\
\hline
\end{tabular}

Notes. This table reports the financial and innovative performance of ECF firms and matched NECF firms that raised other sources of capital. The profitability measure is winsorized at the $5 \%$ level. The overall failure rate and patent data are measured at the end of December 2017 . The significance 
level for the differences in median and mean between both groups are reported. $\dagger, *, * *, * * *$ report significant levels at the $10 \%, 5 \%, 1 \%$, and $0.1 \%$ levels, respectively. 
TABLE 3

DESCRIPTIVE STATISTICS OF THE ONE-TO-ONE SAMPLE OF ECF FIRMS WITH DIRECT SHAREHOLDERS AND NOMINEE STRUCTURE

\begin{tabular}{|c|c|c|c|c|c|c|c|c|c|c|}
\hline \multirow[t]{2}{*}{ Industry distribution } & \multicolumn{2}{|c|}{ Year 0} & \multirow[t]{2}{*}{ Age } & \multicolumn{2}{|c|}{ Year 0} & \multirow[b]{2}{*}{$\mathrm{p}$} & \multirow[t]{2}{*}{ Profitability } & \multicolumn{2}{|c|}{ Year 0} & \multirow[b]{2}{*}{$\mathrm{p}$} \\
\hline & Direct & Nominee & & Direct & Nominee & & & Direct & Nominee & \\
\hline Wholesale, Retail, and Some Services & 0.13 & 0.13 & Median & 2.00 & 2.00 & 0.28 & Median & -0.78 & -0.42 & 0.11 \\
\hline Finance & 0.15 & 0.15 & Mean & 2.26 & 2.38 & 0.24 & Mean & -1.65 & -1.18 & 0.07 \\
\hline Other industries & 0.64 & 0.64 & SD & 1.71 & 1.5 & & SD & 2.26 & 1.79 & \\
\hline Manufacturing & 0.05 & 0.03 & Number of firms & 125 & 125 & & Number of firms & 125 & 125 & \\
\hline \multirow[t]{7}{*}{ Consumer Non Durables } & 0.02 & 0.02 & & & & & & & & \\
\hline & & & Size & $\mathrm{Ye}_{\mathrm{C}}$ & Ir 0 & & Intangible assets & & $\operatorname{ar} 0$ & \\
\hline & & & & Direct & Nominee & $\mathrm{p}$ & ratio & Direct & Nominee & $\mathrm{p}$ \\
\hline & & & Median & 114,954 & 103,932 & 0.27 & Median & $0 \%$ & $0 \%$ & 0.16 \\
\hline & & & Mean & 202,549 & 179,016 & 0.44 & Mean & $8 \%$ & $5 \%$ & 0.23 \\
\hline & & & SD & 260,917 & 222,361 & & $\mathrm{SD}$ & $17 \%$ & $17 \%$ & \\
\hline & & & Number of firms & 125 & 125 & & Number of firms & 125 & 125 & \\
\hline
\end{tabular}

Notes. This table relates to the one-to-one matched sample of ECF firms with direct shareholder structure and ECF firms with nominee structure. The matching variables include industry, firm age and firm size. The table shows the industry distribution (Fama and French 12 industries classification) for the distinct types of ECF firms, and the descriptive statistics for firm age and firm size (total assets in $£$ ). The table also provides additional descriptive data on firm profitability and intangible assets ratio $(\%)$. We use a cut-off, so that industries representing less than $2 \%$ of the sample are not reported for space considerations.

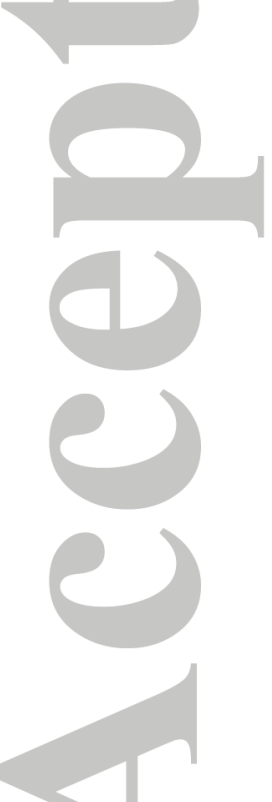

This article is protected by copyright. All rights reserved. 
TABLE 4

FINANCIAL AND INNOVATIVE PERFORMANCE FOR ECF FIRMS WITH DIRECT SHAREHOLDER AND NOMINEE STRUCTURE

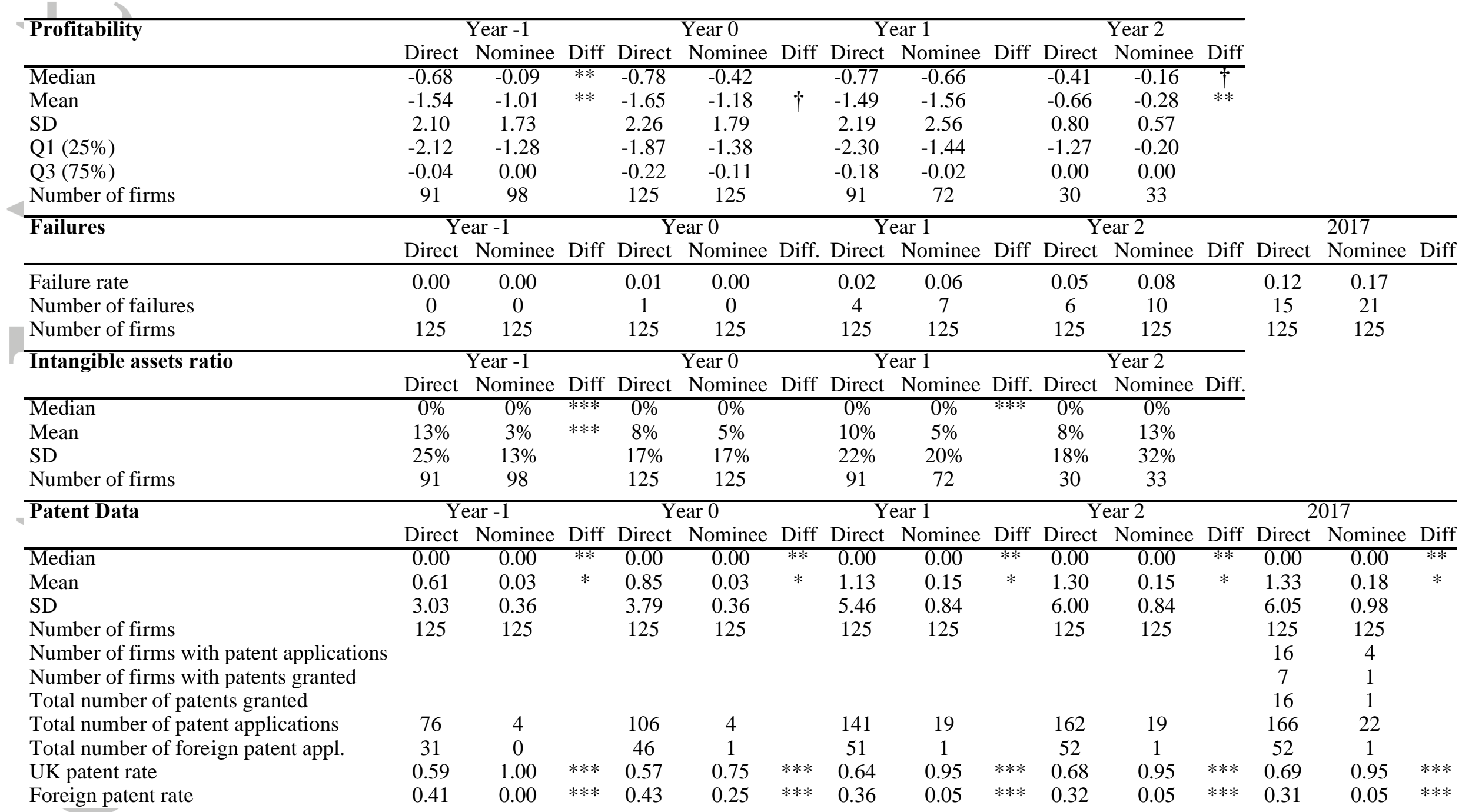

This article is protected by copyright. All rights reserved. 


\section{TABLE 4 - continued}

FINANCIAL AND INNOVATIVE PERFORMANCE FOR ECF FIRMS WITH DIRECT SHAREHOLDER AND NOMINEE STRUCTURE

Notes. This table reports the financial and innovative performance of ECF firms with direct shareholders and ECF firms with nominee structure. The profitability measure is winsorized at the 5\% level. The significance level for the differences in median and mean between both groups are reported. The patent success rate (end of December 2017) is measured as the percentage of patents applications that are actually granted. Foreign patent rate is the percentage of patents applications outside the UK. $\dagger, *, * *, * * *$ report significant levels at the $10 \%, 5 \%, 1 \%$, and $0.1 \%$ levels, respectively. 